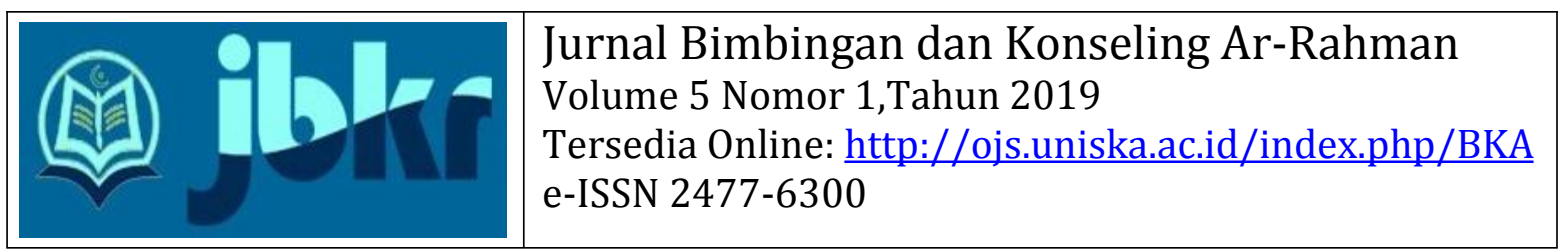

\title{
PELAKSANAAN LAYANAN KONSELING BERBASIS BIRO (STUDI DESKRIPTIF PADA BIRO KONSELING EDUPOTENSIA FOUNDATION BANDUNG)
}

\author{
Hanna Permata Hanifa, Ratna Kusumaningtyas, Resha Yusmar Arvianto \\ Jurusan Bimbingan dan Konseling Fakultas Ilmu Pendidikan Universitas Negeri Semarang \\ permatahanna6@gmail.com/085642173213
}

\begin{abstract}
ABSTRAK
Kebutuhan akan manfaat pelayanan BK kian dirasakan masyarakat secara luas. Keberadaan BK di Indonesia memang berawal dari dunia pendidikan. Seiring perkembangannya, organisasi biro penyedia jasa layanan BK mulai bermunculan di tengah masyarakat. Namun tidak semuanya asli berlatar belakang lulusan BK, melainkan dari jurusan Psikologi. Keadaan ini mendorong berdirinya organisasi atau yayasan biro penyedia jasa layanan konseling yaitu Edupotensia Foundation. Edupotensia Foundation memberikan layanan Konseling yang dilakukan langsung oleh konselor profesional dan lulusan BK sendiri. Kegiatan konseling berbasis biro bagi perkembangan dunia konseling di Indonesia menjadi hal baru yang harus terus dikembangkan. Penelitian ini menggunakan metode kualitatif dengan alat pengumpulan data berupa wawancara mendalam guna mendapatkan informasi secara rinci. Hasil yang didapat melalui penelitian ini adalah pelaksanaan konseling oleh Edupotensia Foundation dilakukan sesuai dengan prinsip, fungsi dan asaz konseling, berfokus pada pendekatan $C B T$, SFBT dan Life-Choaching. Selain itu, Edupotensia Foundation juga memberikan workshop pengembangan kompetensi konseling dan beragam pelatihan yang sesuai.
\end{abstract}

Kata Kunci: Layanan Konseling; Berbasis Biro; Luar Sekolah

\section{ABSTRACT}

The need for benefits from Guidance and Counseling services is increasingly felt by the community at large. The existence of Guidance and Counseling in Indonesia does start from the world of education. Along with its development, the bureau organization of Guidance and Counseling service providers began to appear in the community. However, not all of them are from Guidance and Counseling background, but from the Department of Psychology. This situation encourages the establishment of a bureaus organization or foundation for counseling service providers namely Edupotensia Foundation. Edupotensia Foundation provides Counseling services conducted directly by professional counselors and Guidance and Counseling graduates themselves. Bureau-based counseling activities for the development of the world of counseling in Indonesia are new things that must continue to be developed. This study uses qualitative methods with data collection tools with in-depth interviews to obtain detailed information. The results obtained through this study are that the implementation of counseling by the Edupotensia Foundation is carried out in accordance with the principles, functions and counseling, focusing on the CBT, SFBT and Life-Choaching approaches. In addition, the Edupotensia Foundation also provides counseling competency development workshops and a variety of appropriate training.

Keywords : Counseling Service; Bureau-based; outside School

Dipublikasikan Oleh :

UPT Publikasi dan Pengelolaan Jurnal

Universitas Islam Kalimantan Muhammad Arsyad Al-Banjari Banjarmasin 


\section{PENDAHULUAN}

Sejarah masuknya Bimbingan dan Konseling ke Indonesia berawal dari ranah pendidikan sehingga baru dikenal sebatas salah satu fasilitas yang ada di lingkup sekolah. Sebagaimana yang dikuatkan dalam UU No 20 Tahun 2003 tentang Sistem Pendidikan nasional yang menegaskan dalam pendidikan di Indonesia, konselor dipandang sebagai pendidik. Selebihnya kedudukan konselor dikuatkan dengan adanya peraturan-peraturan lain seperti Pasal 1 ayat (6) UU No. 20 Tahun 2003 tentang Sistem Pendidikan Nasional, Peraturan Pemerintah No 19 tahun 2005 Tentang SNP, Permendikbud 81 A Tahun 2003, dan Permendikbud 111 Tahun 2014.

Konseling sendiri dimaknai sebagai suatu proses bantuan bernuansa psikis dan non-material dari seorang ahli yang disebut dengan konselor kepada klien yang merupakan individu dalam masa perkembangannya guna memandirikan, mengentaskan masalahnya dan mengaktualisasikan dirinya. Senada dengan yang disampaikan oleh Prayitno dan Amti (2004:105) bahwa definisi konseling adalah suatu proses pemberian bantuan yang dilakukan melalui wawancara konseling oleh seorang ahli (disebut konselor) kepada individu yang sedang mengalami suatu masalah (disebut klien) yang bermuara pada teratasinya masalah yang dihadapi oleh klien. Layanan Bimbingan dan Konseling ini diharapkan mampu untuk membantu individu-individu yang membutuhkan bantuan psikis yang hanya dapat dilakukan oleh profesional.

Layanan konseling masih terbagi dalam beberapa jenis layanan, diantaranya layanan konseling individu, konseling kelompok, bimbingan kelompok dan bimbingan klasikal. Jenis layanan konseling mencakup berbagai bidang, yaitu bidang pribadi, sosial, karir, belajar, agama dan keluarga. Konseling berpotensi bermanfaat bagi keberlangsungan kehidupan pribadi yang bahagia dan teraktualisasi, dan mengentaskan masalah yang menghambat individu.

Sebagaimana pelaksanaan Bimbingan dan Konseling di Indonesia masih terfokus sebagai salah satu fasilitas di sekolah. Setiap instansi pendidikan memiliki kekhasan masing-masing dalam sisi pelaksanaan Bimbingan dan Konseling. Berdasarkan pada penelitian Aminah, dkk (2014) terkait pengembangan model program Bimbingan dan Konseling berbasis karakter di sekolah dasar yang juga mencoba melihat pelaksanaan Bimbingan dan Konseling pada jenjang sekolah dasar menunjukkan bahwa program Bimbingan dan Konseling di sekolah dasar belum sesuai dengan kebutuhan siswa. Hasil penelitian tersebut didapatkan karena pada pelaksanaan Bimbingan dan Konseling di sekolah dasar tempat objek penelitian tidak dilakukan berdasarkan hasil analisis need assesment terlebih dahulu. Selain itu, pelayanan terbatas pada ranah kuratif dan insidental, tanpa program terjadwal dan sistematis.

Sedangkan dalam penelitian yang dilakukan oleh Rahmawati (2016) yang mencoba mendeskripsikan pelaksanaan Bimbingan dan Konseling bagi santri baru pada pesantren. Pelaksanaan Bimbingan dan Konseling pada lingkup pesantren dapat dikatakan sesuatu yang jarang. Karena biasanya proses pembimbingan santri pada lingkup pesantran langsung dibawah arahan kyai, guru pesantran atau wali kamar. Hasil penelitian didapatkan bahwa pelaksanaan Bimbingan dan Konseling yang dilakukan pihak pesantren dapat dikatakan kurang maksimal. Penelitian dengan mengambil objek penelitian pada pesantren Al-Mukmin Muhammadiyah Tembarak Temanggung ini mengungkapkan bahwa para santri lebih menyukai bercerita dengan para senior atau ustad pendamping yang dirasa dekat dengan mereka dibanding pergi konsultasi dengan guru Bimbingan dan Konseling atau kesantrian. Kendala yang terjadi dalam pelaksanaan Bimbingan dan Konseling pada pesantren Al-Mukmin adalah kurangnya komunikasi antara pihak pesantren dengan orang tua sehingga konselor kekurangan informasi atas santri yang bersangkutan. Kendala lainnya adalah pelaksanaan konseling yang bersifat kasuistik sehingga konseling dilaksanakan ketika telah mengerucut menjadi suatu pelanggaran. Kendala yang terakhir adalah karena beberapa santri yang berasal dari lingkungan pesantren diperbolehkan untuk tidak tinggal di asrama sehingga membawa pengaruh terhadap budaya pondok yang sudah diterapkan.

Pada lingkup yang berbeda, pelaksanaan Bimbingan dan Konseling yang diteliti oleh Kholili, dkk (2017) memilih objek penelitian pada taman kanak-kanak yang salah satu tujuan penelitiannya adalah untuk menganalisis model faktual pelaksanaan program Bimbingan dan Konseling di TK Al-Hikmah dan TK Khadijah Pandegiling. Hasil penelitian yang didapat menunjukkan bahwa untuk pelaksanaan Bimbingan dan Konseling di TK Khadijah tidak dilaksanakan secara independen sedangkan pada TK AL-Hikmah sudah dilakukan secara independen. Sedangkan hasil uji validasi ahli menilai model yang dikembangkan dinyatakan satu ahli dengan sangat layak diterapkan, empat ahli menilai layak digunakan dan satu ahli cukup layak. Hasil uji ahli oleh praktisi, empat praktisi menilai sangat layak dan empat praktisi lainnya menilai layak digunakan.

Sedangkan dalam jenjang SMP, pada penelitian yang dilakukan oleh Karina (2015), terkait pelaksanaan Bimbingan dan Konseling pada dua SMP yang berbeda yaitu SMP Stella Duce 1 dan SMP Muhammadiyah 2 Yogyakarta. Hasil penelitian yang didapatkan adalah Bimbingan dan Konseling SMP 
Stella Duce menggunakan pola BK-17 sedangkan Bimbingan dan Konseling SMP Muhammadiyah 2 menggunakan pola komprehensif. Pada tahap persiapan, BK SMP Stella Duce menggunakan observasi dan Bimbingan dan Konseling SMP Muhammadiyah 2 mengunakan DCM. Tahap pelaksanaan Bimbingan dan Konseling SMP Stella Duce layanan klasikal tidak terjadwal dan durasi 40 menit, sedangkan Bimbingan dan Konseling SMP Muhammadiyah 2 dua jam pelajaran dalam satu minggu. Pada konseling sebaya, Bimbingan dan Konseling SMP Stella Duce tidak melaksanakan, sedangkan Bimbingan dan Konseling SMP Muhammadiyah 2 melaksanakan. Pada layanan bimbingan kelompok, Bimbingan dan Konseling SMP Stella Duce melaksanakannya di sekolah, sedangkan Bimbingan dan Konseling SMP Muhammadiyah 2 melakukan bimbingan kelompok dengan outbond di luar sekolah. Pada layanan pendukung, Bimbingan dan Konseling SMP Stella Duce berupa kunjungan rumah sakit sedangkan Bimbingan dan Konseling SMP Muhammadiyah 2 tidak memiliki layanan pendukung. Terakhir, dokumentasi Bimbingan dan Konseling SMP Stella Duce lebih lemah dibanding Bimbingan dan Konseling SMP Muhammadiyah 2 yang sangat lengkap.

Berkaca pada kondisi Bimbingan dan Konseling dalam lingkup sekolah, nyatanya masih banyak hal yang harus diperbaiki dan dikembangkan. Bimbingan dan Konseling dalam lingkup sekolah atau pendidikan belum menunjukkan tingkat kepuasan dan efektivitas kinerja yang baik. Terkait hal ini, sudah banyak termuat dan dibahas dalam beragam kajian ilmiah, baik jurnal maupun skripsi. Diantaranya seperti yang ditemukan oleh Wulandari (2007) berupa ada beberapa hambatan dalam pelaksanaan bimbingan konseling terutama pada konseling kelompok di SMP Negeri se-Kabupaten Wonogiri.

Namun demikian, seiring dengan perkembangannya, mulai tumbuh organisasi, lembaga dan komunitas yang mencoba membawa kebermanfaatan konseling pada ranah atau lingkup yang lebih luas. Meski belum menjadi gerakan nasional serta belum ada data yang merangkum jumlah organisasi atau biro konseling swasta secara nasional. Dengan beragam inovasi yang dibawa, mereka mencoba mendekatkan manfaat konseling pada kehidupan keseharian khalayak umum. Kondisi ini masih belum banyak diangkat dalam penelitian maupun jurnal terkait bagaimana organisasi, komunitas, yayasan maupun biro dalam memberikan layanan Bimbingan dan Konselingnya terhadap masyarakat.

Kesesuaian dan ketepatan pelaksanaan konseling menjadi hal yang penting untuk diperhatikan. Hal ini dikarenakan pelaksanaan konseling yang sesuai dengan standar dan dasar keilmuwan dapat menghasilkan layanan bantuan tepat dan bermanfaatan secara efektif serta efisien bagi klien. Selain itu, juga dapat meningkatkan kepercayaan masyarakat atas pelayanan Bimbingan dan Konseling yang ada. Hal ini yang sebenarnya sedang dituju untuk dicapai oleh semua pihak yang bergerak dalam bidang Bimbingan dan Konseling.

Pelaksanaan konseling pada biro pelayanan konseling tidak dapat dibandingkan dengan pelaksanaan konseling pada lembaga-lembaga rehabailitas di bawah naungan pemerintah dan medis. Lembaga-lembaga rehabilitasi di bawah naungan pemerintah dan medis sering kali menjadi rujukan oleh lembaga terkait pada kasus-kasus tertentu di masyarakat. Sedangkan pelaksanaan konseling pada lembaga swadaya masyarakat, sering kali tidak memenuhi standar pelaksanaan konseling sebagai proses profesional. Sehingga hal ini penting untuk menjadi perhatian bersama terkait bagaimana biro pelayanan konseling melaksanakan konseling sebagai proses profesional secara mandiri, mempromosikan diri dan kebermanfaatan konseling pada masyarakat. Biro pelayanan konseling ditantang untuk dapat bertahan dan terus berkembang sesuai permintaan zaman dan menjawab kebutuhan masyarakat.

Salah satu biro konseling yang sudah berkegiatan bersama masyarakat adalah Edupotensia Counseling. Sebuah biro konseling yang berbadan hukum yayasan, dengan nama Edupotensia Foundation dengan fokus pelayanan pada konseling, assesment, dan hipnoterapi serta didukung oleh tenaga ahli sesuai di bidangnya. Edupotensia Counseling memberikan figur yang baik sebagai biro pelayanan konseling di Indonesia.

Pemilihan Edupotensia Counseling sebagai lokasi penelitian dilakukan berdasarkan beberapa pertimbangan, diantaranya adalah Edupotensia Counseling sudah berbadan hukum, tenaga ahli berasal dari lulusan Bimbingan dan Konseling, Edupotensia memiliki lisensi untuk melakukan layanan assessment, sudah berkegiatan secara riil dengan masyarakat. Pertimbangan-pertimbangan tersebut menjadi penting, karena pada umumnya sebagian biro pelayanan dan konsultasi lebih banyak dikembangan oleh lulusan Psikologi. Tidak hanya memiliki badan hukum, Edupotensia Counseling didukung oleh kesiapan sistem operasional dan prosedur kerja yang tertata. Edupotensia Counseling juga menjunjung kode etik profesi konselor. Sebuah isu dari pelayanan konseling yang cukup serius untuk diperhatikan.

Hal ini menjadi penting bagi perkembangan ilmu dan praktik Bimbingan dan Konseling di Indonesia. Pelaksanaan konseling berbasis biro pelayanan konseling di Indoenesia dapat terbilang 
masih baru. Ranah ini sama pentingnya dengan pelaksanaan konseling pada lingkup sekolah. Jumlah jurnal mengenai penelitian terkait konseling berbasis luar lingkup sekolah pun masih terbilang sedikit dibandingkan jurnal penelitian di lingkup sekolah, sehingga penelitian ini layak dilakukan.

\section{METODE}

Penelitian ini menggunakan metode deskriptif kualitatif. Teknik pengumpulan data In Depht Interview dan dokumentasi. Isntrumen penelitian adalah peneliti sebagai instrument (Human Instrument serta tape recorder. Sampel yang digunakan adalah non-probability sampling yaitu purposive sampling.

\section{HASIL DAN PEMBAHASAN}

Profil dan Sejarah Edupotensia Counseling

Cikal bakal berdirinya Edupotensia Counseling dimulai dari ide atau gagasan sekumpulan mahasiswa tahun ketiga Stara 1 Prodi Bimbingan dan Konseling Univeristas Pendidikan Indonesia mengenai disiplin ilmunya, terutama hipnoterapi yang saat itu belum berkembang seperti sekarang. Edupotensia Counseling mulai berkegiatan sejak tahun 2009 di bawah naungan Edupotensia Foundation. berselang 2 tahun sejk berdiri yaitu tahun 2011, Edupotensi mulai sering menerima jasa layanan konseling, terus berkembang pada tahun 2014 memasuki ranah assessment hingga pada tahun 2017 menjadi badan hukum resmi yaitu yayasan Edupotensia Counseling yang bergerak di bidang layanan konseling sebagai fokus utama serta assessment dan hipnoterapi.

Tim dari Edupotensia Counseling, baik pengurus yayasan maupun pengurus biro merupakan lulusan-lulusan Bimbingan dan Konseling dari berbagai Univeristas di Indonesia serta menjadi staf pengajar di Universitas pula, seperti Universitas Muhammadiyah Tasikmalaya, Universitas Pendidikan Indonesia, dan Universitas Maksum.

Edupotensia Counseling memiliki visi utama yaitu membantu dalam mengoptimalkan potensi manusia sehingga menemukan makna hidup untuk kesuksesan dan kebahagiaan hidup, dengan slogannya "Empowering Your True Potential." Arah kegaitan Edupotensia Counseling terdeskripsikan melalui visi dan misi, sebagai berikut:

1) Visi

Menjadi salah satu lembaga training dan counseling service provider terkemuka di Indonesia dengan menyediakan program pengembangan diri yang berkualitas dan menjadi solusi untuk klien. Selain itu, juga menjadi lembaga pengembang keterampilan konseling dan psikoterapi di Indonesia.
2) Misi

(a) Edupotensia menjawab kebutuhan akan penyediaan training dan program pembelajaran bagi pengembangan individu dan kelompok dengan berbasis pada pengembangan potensi manusia

(b) Edupotensia menjawab kebutuhan organisasi akan program dan solusi pengembangan organisasi yang berkualitas dan nyata untuk menjawab permasalahan dan kebutuhan organisasi

(c) Edupotensia menjawab kebutuhan akan ideide bermutu, aplikatif dan up-to-date dalam pengembangan keilmuan konseling dan psikoterapi di Indonesia

(d) Edupotensia aktif dalam melakukan penelitian dan pengembangan di dunia konseling dan psikoterapi yang up-to-date dan aplikatif baik dalam setting pendidikan maupun masyarakat pada umumnya

Masyarakat Indonesia pada umumnya masih awam tentang Psikolog atau Konselor, sehingga perlunya mengedukasi masyarakat. Seiring berjalannya waktu, masyarakat menyadari akan keterbutuhan konseling hal ini yang membuat Edupotensia semakin berkembang. Walaupun demikian, Edupotensia Counseling adalah lembaga yang mandiri, bersifat otonom, dan bukan di bawah naungan satuan pendidikan tertentu, sehingga Edupotensia Counseling berusaha untuk menjaga integritas lembaga. Namun Edupotensia Counseling tidak menutup hubungan kerja sama dengan lembaga lainnya.

\section{Kegiatan Promosi Layanan dan Kerjasama}

Masyarakat era milineal tentu sangat dekat dengan internet. Memanfaatkan teknologi, salah satu teknik promosi yang digunakan untuk lebih mengenal dan menyebarluaskan Edupotensia adalah promosi secara online. Klien yang membutuhkan bantuan Edupotensia dapat mencari pada aplikasi Google Maps dengan keyword tertentu, kemudian nama lembaga akan muncul dan dapat menjadi rekomendasi klien untuk datang berkonsultasi dengan para konselor di Edupotensia. Selain itu, Edupotensia merambah aplikasi social media seperti Instagram, dan Faceebook atau melalui referral dari sekolah mitra. Cara tradisional dari mulut ke mulut pun idak luput sebagai media promosi yang masih terbilang efektif.

\section{Bidang Layanan Edupotensi Counseling}

Edupotensi Counseling menyediakan dua jasa pelayanan, yaitu Konseling dan Hipnoterapi. Dalam prosesnya, tak jarang klien secara langsung meminta untuk diberikan treatmen tapi ingin melalui proses konseling terlebih dahulu. Layanan ini sejalan 
dengan focus dan fungsi lembaga Edupotensi Counseling yang mengarah kepada proses konseling serta sesuia dengan ilmu dari para terapis atau konselor yang berlatar belakang Bimbingan dan Konseling sehingga akan lebih mengutamakan dan mengarahkan klien untuk melakukan sesi konseling disbanding hipnoterapi.

Secara umum, Edupotensia Counseling juga menyediakan jasa pelatihan dan workshop pengembangan kualifikasi kompetensi di bidang Bimbingan dan Konseling. Layanan workshop dan pelatihan dari Edupotensia Counseling ditujukan langsung untuk pengembangan sumber daya manusia, seperti pengembangan softskill pada siswa, serta membantu perencanaan karir siswa. Workshop atau pelatihan yang diadakan pun untuk pengembangkan kompetensi konseling melalui pendekatan Solution Focus Brief Therapy (SFBT), Cognitive Behavior Therapy (CBT), dan Life-Coaching.

Workshop yang diadakan oleh Edupotensi tidak semuanya berbayar, ada juga workshop yang diberikan secara gratis kepada sekolah mitra maupun non-mitra. Pada awal berdirinya layanan berupa workshop ini lebih banyak diminati oleh profesi nonBimbingan dan Konseling atau Psikolog untuk memberikan pelatihan hipnoterapi. Semakin berkembang, banyak dari profesi Bimbingan dan Konseling yang berkegiatan bersama Edupotensia dalam meningkatkan kemampuan paedagogik maupun kemampuan profesional. Edupotensia juga memiliki lisensi dalam melakukan praktik assessment oleh anggotanya serta alat tes terstrandar dari Universitas Negeri Malang. Sejauh ini belum ada kerja sama antara Psikolog dalam mengembangkan alat tes, kecuali memang diadakan kerja sama antar kedua profesi.

Berkembangnya teknologi revolusi industry 4.0 membuat banyak lembaga sejenis sudah mengembangkan Cybercounseling. Edupotensia tetap berkegiatan memberikan layanan secara tatap muka (face to face) kepada klien yang membutuhkan. Komunikasi secara online digunakan sebagai sistem pendukung namun bukan sebagai pemberian layanan utama.

\section{Konselor Edupotensia Counseling}

Konselor atau terapis yang berada di Edupotensia Counseling telah memiliki kualifikasi dan spesifikasi yang terintegritas. Para konselor atau terapis minimal berpendidikan Sarjana Strata 1 Bimbingan dan Konseling, Lulusan Pendidikan Profesi Konselor (PPK), Sarjana Stara II (Magister) Bimbingan dan Konseling, serta beberapa Konselor sedang menempuh pendidikan Strata III (Doktor) pada konsentrasi Bimbingan dan Konseling. Selain jenjang pendidikan, hampir semua Konselor atau terapis memiiki kompetensi non-akademik, seperti Certified Hypnotherapy Therapist (CHT), dan Non Lisensed Profession (NLP) dan Life-Coaching. Pendekatan ini pun sudah diajarkan di ranah pendidikan, namun secara umum, belum menyeluruh dipelajari.

Secara resmi, tim dari Edupotensia Counseling hanya berjumlah tujuh konselor, akan tetapi meiliki banyak tim dibawahnya dan juga konselor freelance yang memiliki legal standing sebagai konselor dan menerima layanan konseling di bawah lembaga Edupotensia Counseling.

Untuk pembagian divisi kerja, Edupotensia Counseling memiliki tiga divisi utama. Pertama, divisi konseling adalah divisi untuk mengurus berbagai hal terkait konseling. Kedua, divisi pengembangan sumber daya manusia adalah divisi yang mengelola kegiatan berkaitan dengan workshop dan memberikan kegiatan dukungan sistem untuk pemberian motivasi, serta pelatihan assesment. Ketiga, divisi assesment, adalah divisi yang memberikan assesment psikologis dengan lisensi dan alat tes terstandar.

\section{Pelaksanaan Konseling Edupotensia Counseling}

Untuk pelayanan konseling, Edupotensia Counseling memiliki prosedur sebagai berikut:

1. Permohonan dari klien

Calon klien akan terlebih dahulu menghubungi Edupotensia Counseling, baik melalui e-mail maupun telepon, kemudian diarahkan untuk melakukan korespondensi atau pengarahan oleh staf Edupotensia Counseling. Adanya konsultasi awal untuk meyakinkan permasalahan klien dan juga menjelaskan tentang sistem prosedur Edupotensia Counseling, terkait background Edupotensia Counseling secara akademis kemudian layanan yang Edupotensia Counseling miliki selalu disampaikan jelas kepada klien.

\section{Pengisian kontrak}

Setelah klien mengetahui pelayanan di Edupotensia Counseling dan mereka yakin mengambil sesi konseling dengan Edupotensia Counseling, maka tim akan mengarahkan ke kontrak terkait ada berapa sesi, terkait pembiayaan berapa, dan untuk komitmen klien atas konsisten dalam melakukan layanan.

3. Pengisian intern form

Intern form berupa lembar pernyataan atau pertanyaan yang akan diisi oleh klien dan kemudian akan dijadikan dasar pemberian layanan. Sebelumnya klien sudah memberikan informasi gambaran terkait masalah yang dialami atau targetan apa yang ingin dicapai selama konseling,. Intern form sebagai dokumen atau data tertulis yang akan digunakan oleh tim Edupotensia 
Counseling sebagai pertimbangan dalam pemberian bantuan kepada klien yang sesuai dengan permasalahan klien tersebut, serta untuk memahami kondisi khusus dari klien yang akan ditangani. Misalnya klien memiliki riwayat penyakit jantung sehingga memungkinkan ada beberapa teknik yang tidak bisa diterapkan pada klien tersebut, atau klien sedang berada dalam penangann dokter sehingga mengkonsumsi obatobat tertentu dan itu akan mempengaruhi proses konseling. Kemudian apabila dalam pemberian layanan hipnoterapi, ada teknik tertentu yang daopat digunakan, misal warna kesukaannya, atau terkait status klien, kemudian bagaimana hubungan relasi dengan keluarga. Informasi dalam intern form sangat penting dalam mendukung kelancaran proses konseling.

4. Penjadwalan sesi konseling dan konselor yang menangani

Saat klien sudah mengisi intern form, lalu diserahkan kembali ke tim Edupotensia Counseling untuk didiskusikan dengan tim perihal layanan yang akan diberikan, disesuaikan dengan pengalaman dan kasus yang sudah pernah ditangani oleh konselor tersebut. Selanjutnya, bagian administrasi Edupotensia Counseling akan berkoordinasi dengan klien dan konselor terkait waktu penjadwalan konseling. Kemudian ada kesepakatan antar dua belah pihak dalam menjalin hubungan sesi konseling sesuai kontrak kesepakatan. Biasanya kontrak awal terdiri dari empat sesi, yaitu tiga sesi konseling dan satu sesi evaluasi. Pada setiap sesi, aka nada catatan konseling serta akumulasi dari keseluruhan sesi yang telah berlangsung., sehingga dapat terlihat perubahan yang terjadi pada klien. Bila eandainya tidak terselesaikan oleh terapis pada saat itu, maka akan lebih mudah ketika harus melakukan referel kepada konselor yang lain.

\section{Strukturing}

Untuk sesi awal terdapat kontrak antara klien dan konselor, dan beberapa hal yang harus disampaikan diawal terkait pendokumentasian, attau hal-hal yang secara etik memang diperlukan. Hal ini sangatlah penting, misalnya bagaimana konselor menjaga kerahasiaan klien, menjelaskan tujuan pendokumentasian dilakukan, meminta izin untuk mendiskusikan kasus tersebut kepada konselor lain jika memang terjadi hambatan atau stuck dalam proses konseling, tentu sepengetahuna konseli dan hanya dilakukan dengan supervisor.

Mengenai format layanan yang diberikan akan berbeda tergantung perspektif masing-masing pribadi. Apabila persoalannya adalah individu, maka orang umum akan mengasumsikan kami akan memberikan layanan individu. Namun dalam pelaksanaannya di lapangan, permasalahan setiap orang atau hal-hal yang ingin dikembangkan tidak saja terkait dengan diri pribadinya, bisa saja dalam pelaksanaannya terdapat konseling keluarga. Kemudian juga ketika klien sudah selesai dengan sesi konselingnya dan ia memiliki target lain yang ingin dicapai, maka disediakan layanan Life-Coaching. Apabila dalam perkembangannya klien membutuhkan sebuah softskill untuk mampu menyelsaikan permasalahan, maka Edupotensia Counseling memberikan pelatihan atau training sesuai kebutuhan klien.

Manusia adalah makhluk yang unik.. terkadang pula tidak semua klien yang datang ke Edupotensia Counseling ingin menyelesaikan masalah, beberapa klien datang dengan tujuan memperoleh bantuan untuk mencapai targetan tertentu dalam hidup, maka Edupotensia Counseling bantu dengan coaching serta support-support sistem untuk membantu klien mencapai targetnya.

Pada perkembangannya, Life-Coaching memang tren dari barat namun sudah mulai berkembang di Indonesia. Memiliki fungsi seperti bimbingan yang memiliki target dan tujuan yang ditentukan oleh klien kemudian coach membimbing hingga mencapai target tersebut, atau dikenal dengan istilah protokol dan tools. Protokol seperti kata-kata kunci ketika kita melakukan konseling, bagaimana tata cara ketika kita bertanya dan bagaimana kita merespon. Sedangkan tools adalah alat-alat yang dipergunakan dalam membangun paradigma seseorang dalam mencapai targetannya.

\section{Permasalahan Umum Klien Edupotensia Counseling}

Permasalahan yang ditangani Edupotensia Counseling sangat beragam. Pada kalangan pelajar dari sekolah mitra maupun non sekolah mitra, mulai dari motivasi belajar dan anak yang membolos. Sedangkan untuk orang dewasa, biasanya tentang merencanakan karir, hubungan interpersonal, konflikkonflik keluarga dan permasalahan dengan rekan kerja bahkan atasan, tak jarang permasalahan tentang manajemen stres, isu terkini seperti LGBT dan permasalahan seksual juga sempat menjadi kasus yang Edupotensia Counseling tangani. Permasalahan yang belakangan ini cukup sering adalah kasus adiksi seperti adiksi game online, adiksi internet, adiksi gadget dan dunia kerja yang semakin bersaing, banyak klien yang mengalami insomnia sehingga akibatnya berpengaruh kepada kesehatan, ini dapat menjadi hal luar biasa bagi sebagian orang. Secara keseluruhan karena bekerja sama dengan sekolah, tentu klien dari sekolah lebih banyak. 


\section{PENUTUP}

Keberadaan Bimbingan dan Konseling dalam kehidupan keseharian masyarakat sebenarnya sudah menjadi suatu kebutuhan. Namun kenyataan di lapangan, kesungkanan untuk berkonsultasi pada profesional dan istilah konselor yang belum familiar bagi masyarakat awam menjadi isu yang harus diperhatikan terutama bagi lulusan Bimbingan dan Konseling. Kebutuhan akan adanya biro konseling dengan stakeholder linear Bimbingan dan Konseling mulai tampak. Biro Konseling Edupotensia Foundation sebagai salah satu biro konseling yang berfokus pada pemberian layanan konseling dan hipnoterapi, assesment, pelatihan dan workshop dapat menjadi figur acuan untuk pengembangan biro konseling yang baik. Dengan tenaga profesional linear lulusan Bimbingan dan Konseling serta dilengkapi dengan kompetensi non akademis yang sesuai, menjadi penguatan positif bagi kebermanfaatan suatu biro konseling. Pelaksanaan konseling berbasis biro yang baik menjadi kampanye yang efektif untuk mengikis miskonsepsi kebermanfaatan bimbingan dan konseling yang selama ini terjadi di masyakat.

\section{REFERENSI}

Aminah, Siti, dkk. 2014. Pengembangan Model Program Bimbingan dan Konseling berbasis Karakter Di Sekolah Dasar. Jurnal Bimbingan dan Konseling. Vol 3 no. 1 hlm 72-75

Karina, Windi. 2015. Studi Komparatif Layanan Bimbingan dan Konseling SMP Stella Duce 1 dan SMP Muhammadiyah 2 Yogyakarta. SKRIPSI. Universitas Islam Suann Kalijaga Yogyakarta.

Kholili, Ma'rifatin Indah, dkk. 2017. Model Program Bimbingan dan Konseling Komprehensif Di Taman Kanak-Kanak. Jurnal Bimbingan dan Konseling. Vol 6 no 2 hlm 159-166

Peraturan Pemerintah No 19 tahun 2005 Tentang Standar Nasional Pendidikan

Permendikbud 81 A Tahun 2003 tentang Implementasi Kurikulum

Permendikbud 111 Tahun 2014 tentang Bimbingan dan Konseling

Prayitno dan Amti E. 2004. Dasar-Dasar Bimbingan dan Konseling (Cetakan Ke-2). Jakarta : Rineka Cipta.

Rahmawati, Ruchaini Fitri. 2016. Konseling Budaya Pesantren (Studi Deskriptif Terhadap Pelayanan Bimbingan Konseling Bagi Santri Baru). Konseling Religi: Jurnal Bimbingan Konseling Islam. Vol7 no 1 hlm 61-84
Sugiyono. 2013. Metode Penelitian Kuantitatif, Kualitatif, dan R\&D (Cetakan Ke-18). Bandung: Alfabeta.

Undang-Undang No 20 tahun 2003 tentang Sistem Pendidikan Nasional.

Wulandari, Betty. 2013. Hambatan Pelaksanaan Layanan Konseling Kelompok di Sekolah Menengah Pertama (SMP) Se-Kabupaten Wonogiri Tahun Ajaran 2012/2013. Skripsi. BK FIP UNNES.

Dipublikasikan Oleh :

UPT Publikasi dan Pengelolaan Jurnal

Universitas Islam Kalimantan Muhammad Arsyad Al-Banjari Banjarmasin 